which some new details are here given, in addition to the description contained in J.A.S.B., 1897. Kāvya, dramas, both Sanskrit and Nepalese, lexicography, politics, erotics, systems of philosophy, Buddhism, epics and Purānas, stotras, and other branches of Sanskrit learning are also well represented, and there is an enormous amount of Tāntrika literature.

Altogether, this is one of the most valuable Sanskrit catalogues published of late years, and a future Aufrecht will be able to use it as an excellent basis for compiling a supplement to that useful work, the Catalogus Catalogorum.

\title{
J. JoLLx.
}

Dictionsaire C̆́am-Français. Par Etienne Aymoniek, Résident Supérieur Honoraire, Ancien Directeur de l'Ecole Coloniale, et Astoink Cabaton, Attaché à la Bibliothèque Nationale, Ancien Membre de l'Ecole Française d'Extrême Orient. (Paris: Imprimerie Nationale, Ernest Leroux, 1906.)

It is no easy matter to review a dictionary, unless indeed one does it after the manner of the legendary Scotchman who tackled Dr. Johnson's. In the present case the difficulty is not diminished by the fact that the work in question is the first dictionary that has ever been put together of the Cham language, with which hardly anyone in Europe except its compilers, and certainly not the writer of this notice, can claim an acquaintance at first hand. The authors of this important dictionary are honourably known in connection with previous works on the Chams and their language (as well as other Indo-Chinese peoples and languages), and the present work is a fitting culmination of their labours.

The Chams were formerly a great nation, but are now a mere set of fragments dispersed in various localities, mainly in Camboja and Annam. Their language, of which there are two dialects, that of Camboja and that of Annam, 
is probably doomed to extinction, and is of little practical use as a spoken vernacular. But from the scientific point of view it is of great interest and importance. Regarded as lexicographical material, as one sees it in this dictionary, the language constitutes a most curious jumble. Words of the most diverse origin jostle one another in these pages, the principal elements being Malayo-Polynesian, Mon Khmer, Sanskrit, and Arabic. But one must distinguish : the Sanskrit and Arabic words represent merely the deposit left by the two foreign systems of religion and general culture by which the race has been affected. Hinduism, in a form mainly Sivaite, became at an early date the national religion, and is still (though in a very corrupt and degenerate state) the faith, or rather the cult, of a part of the Chams of Annam. The rest of them, as well as their emigrant cousins in Camboja, are Muhammadans, though the nominally Muslim section of the Chams of Annam retains many pagan beliefs and practices. With the other two elements in their mixed vocabulary the case is very different. Here we are dealing with a much older stratum of the language; or rather with two strata that have been so intimately welded together that learned scholars are still disputing as to which of them is to be considered as representing the original Cham language. On the one side we have Professors Kern and Kuhn, with the authors of this dictionary and the late Professor Niemann, on the other Professor Schmidt and the late Dr. Himly, all very high authorities, differing, if I may vary the metaphor, as to which was the original stock and which the graft.

The problem is a difficult one: what is, in general and in this particular case, to be the ultimate criterion of linguistic classification? The position of Cham in regard to this question may perhaps best be made intelligible by a fictitious parallel instance. If there had never been any such thing in the Romance and Teutonic languages as grammatical inflection, what criterion would one employ to decide into which of these two classes English should be placed? That is pretty closely analogous to the position 
of Cham in relation to the Mon-Khmer and MalayoPolynesian families. If its characteristics are enumerated, it will be found that some of them are distinctly MonKhmer, others as decidedly Malayo-Polynesian. Thus it has, like the Mon-Khmer languages, a strong tendency towards monosyllabism and accentuates the final syllable. As in Achehnese, where these peculiarities also occur, the presence of Mon-Khmer words indicates the cause of this divergence from the normal type of the Malayo-Polynesian languages of the Eastern Archipelago. Partly as a consequence of this peculiarity, Cham (once more like Achehnese) makes a frequent use of aspirated consonants, even in words of Malayo-Polynesian affinity, where they are usually the result of the suppression of the vowel of the penultimate syllable of words whose final syllable begins with $h$. Such cases are jhak, 'wicked' (Malay jahat), jhik, 'to sew' (Malay jahit), thău, 'to know' (Malay tahu), thun, 'year' (Malay tahun). In the Malayo-Polynesian languages aspirated consonants are almost unknown; in the MonKhmer family they are common. Another effect of the accentuation of the final syllable is that the ancient final diphthongs are often preserved, e.g. in such words as apueei, 'fire' (Malay api), motai, 'dead' (Malay mati). To the same cause is doubtless to be attributed the most characteristic of all the peculiarities of Cham phonology (though a few parallels may be found elsewhere), viz. the indifference of the vowel of the penultimate syllable in such cases as akan, ikan, 'fish,' adun, iduin, 'nose,' arak, urak, 'thread,' and the like. This peculiarity makes Cham in some cases an awkward language to disentangle: thus, the words 'prawn' (Malay hudang), 'charcoal' (Malay arang), 'longing' (Malay hidam), 'while' (Malay seedang) are all represented by the Cham word hadan, which is also the name of the Eulales Javanensis, a species of bird that can be taught to talk. On the other hand, it appears that Cham is somewhat less consonantal than the Mon-Khmer languages, and in this respect approaches nearer to the Malayo-Polynesian type, which admits even less of the heaping up of consonants 
than do the Mon-Khmer languages. But in the extent and complexity of its vowel-system Cham is again nearer to the Mon-Khmer family. To some extent the mixture of the Cham phonetic system shows itself even in the treatment of Indian loanwords, some of which, having passed through a Mon-Khmer channel, have been forced into the abbreviated forms usual in that family (and in Indo-China generally), while others retain their fuller forms, as they do in the Indonesian languages. Thus we find dik and $d u k h a k$, representing the Pali dukkha (as well as $d u h k h a k$, from the Sanskrit duhkha), dip, depa and déba (Sanskrit deva), bhum and bhümì (Sanskrit bhümi), and the like. It is noticeable that the Cham words, whether of Indian or Mon-Khmer affinity, have not as a rule shared in the "Lautverschiebung" which has affected Khmer (and to a less extent Mon) phonetics in comparatively modern times; the Cham sonants are not pronounced as surds, and vice versâ.

But, after all, do these considerations help one much towards the solution of the problem? Are not phonetics largely a matter of racial idiosyncrasy, and is a language to be held to have lost its identity when its adoption by an alien community has modified its phonetic system? Is the Pidgin English of the China ports no longer to be considered a Teutonic dialect?

Syntax as a criterion of classification offers much the same difficulties. There is very little difference, in general principles, between the syntactical systems of the MonKhmer and Malayo-Polynesian families. But anyhow, as the case of Pidgin English again illustrates, the transference of a language from one racial community to another is often accompanied by a modification of its syntax, which is really not a principle essentially inherent in the language itself, but rather a form imposed upon it by the mentality of the person speaking it.

Then there is the formative system by means of which words are built up in the languages in question. But this is very similar in the Mon-Khmer and Malayo-Polynesian Downloaded from https://www.cambridge.org/core. University of Leeds, on 24 Sep 2018 at 04:10:52, subject to the
Cambridge Cole Refts? of 907 , available at https://www.cambridge.org/core/terms. 
families, and is not grammatical (i.e. of the nature of accidence) but etymological. On both grounds it is far less conclusive as a criterion of classification than an inflectional system would be. What inference could legitimately be drawn from the existence in English of words with Romance terminations, such as -tion or -ment, even when (as in the word atonement) they are occasionally affixed to words of Teutonic origin? Even if we concede to Professor W. Schmidt that the use of prefixes and infixes in Cham resembles the Mon-Khmer nearer than the Malayo-Polynesian, one cannot but note (as an illustration of the entanglement of the relation of these families) that the very words by which (in "Anthropos," tom. ii, fasc. 2, p. 332) he endeavours to show the existence in Cham of the MonKhmer infix $-p$ - as applied to roots beginning with $l$ - are mostly of Malayo-Polynesian affinity! The prefixes and infixes of the Mon-Khmer and Malayo-Polynesian families respectively being practically identical, much has been made of the existence in the latter family of suffixes, which the former does not possess, and it has generally been stated that Cham in this respect conforms to the Mon-Khmer type. It appears to be true that the most characteristic of Malayo-Polynesian suffixes, -an and -èn, are not recognised as now existing as living elements in the Cham language. But even a casual glance through this dictionary reveals the fact that they have, at any rate, existed in former times. The word samilan, 'nine' (Malay sambilan), is usually regarded as derived from the verb ambil, ' to take.' Salatan, çālatan, 'south' (Malay sĕlatan), is from sèlat, 'strait' (the word is not Arabic, as by a misprint is stated in this dictionary, and the reference is to the straits of the Eastern Archipelago, perhaps the Sunda Straits in particular). Professor Kern has suggested that the word for 'elephant,' in Cham limón, Javanese liman, is derived from lima, the old Malayo-Polynesian word for ' hand.' Here, at any rate, are a few words built up by means of suffix-formation. Unfortunately, though lima exists in Cham (in the form limö', 'five'), the other two stems, ambil and sèlat, apparently Downloaded from https://www.cambridge.org/core. University of Leeds, on 24 Sep 2018 at 04:10:52, subject to the Cambridge Core terms of use, available at https://www.cambridge.org/core/terms. 
do not occur. Must it be inferred that samilan and salatan have been borrowed by Cham from some other MalayoPolynesian tongue? (There are, of course, such loanwords; e.g. padumon, 'magnetic compass,' is undoubtedly from the Javanese padoman (from dom, 'needle'), and turanan, the title of a royal chronicle, may, as the authors suggest, be from the Malay turunan, more usually keeturunan, 'descent'; the Cham forms of the stems contained in these two words are jarum and trun respectively.) Probably a systematic search would reveal other words formed with suffixes, but they cannot be very numerous. It would seem that the old Malayo-Polynesian dialect which entered into the composition of the Cham language made use of this method. If it has become obsolete now, the fact is no doubt due to the influence of the competing Mon-Khmer element.

Admitting, therefore, that the problem as to the proper classification of a language is one that cannot be solved by merely lexicographical evidence, it does, however, seem that under the peculiar circumstances of the present case such evidence must carry great weight. Surely it is of the very first importance that the Cham equivalents for a large number of words in common use are preponderatingly of Malayo-Polynesian affinity. Taking a score or more of the names of parts of the body (human and animal), I find that of the Cham equivalents (some fifty in number) about half are of doubtful, unknown, or foreign (mainly Indian or Arabic) origin, the remainder being to the extent of fourfifths Malayo-Polynesian and only one-fifth Mon-Khmer. Moreover, the Mon-Khmer words appear in several cases to be loanwords taken direct from Khmer or some other neighbouring allied tongue, such as Stieng or Bahnar. With one exception the Mon-Khmer words have synonyms of Malayo-Polynesian origin; but the converse is not the case. These things must have been amongst the very first to which primitive man had to give names; and if the Cham language of to-day still calls them by their ancient Malayo-Polynesian names, it is a strong argument in favour of classing it in that family of speech. Such words are not 
likely to be lost or borrowed wholesale; they are in daily use in the mouths of the people. To my mind they are more likely to be preserved than even numerals and personal pronouns. One knows that Malay, for instance, has borrowed some of these from Sanskrit, while the bazaar jargon that passes for Malay has actually acquired two pronouns from Chinese. Again, Khmer has borrowed its higher numerals from Siamese in comparatively modern times, while Japanese, in addition to its native system, has also taken over the Chinese numerals. Still, it is worth mentioning that the Cham numerals and personal pronouns are Malayo-Polynesian.

In other departments of the vocabulary the preponderance of this element is not so marked. Nevertheless, it exists in the names of colours, while in those of the commoner animals and in words of relationship the balance in favour of the Malayo-Polynesian element is very small. Names of metals are also about equally divided. This is not the place to work out this line of analysis in detail. I have said quite enough to draw attention to the interest attaching to the Cham language as a difficult case in linguistics. The present dictionary will not only be of use in contributing towards the solution of this problem; it is also likely to prove a most valuable help to all students of the MonKhmer and Malayo-Polynesian families of speech.

With a view to facilitating comparative studies in these directions the authors have in many cases given a number of cognate forms from the allied languages. This has added very materially to their. labours, but also to the value of the dictionary. I must not, therefore, be taken as underrating this part of their work when I add that it is by no means complete, and that in a few cases the comparisons cannot be supported. Karamat, 'vertu,' ' bonnes œurres,' 'sainteté,' is, at any rate in the last sense, from the Arabic ${ }^{2} .0$, , not from the Sanskrit karman. Duri, 'precious stone,' is the same as the Malay baiduri, 'opal,' both being of Indian origin. Mojduon and its variant paduo'n, 'assistant minister (or priest),' must, I think, be from the Sanskrit vidvams 
(like the Malay biduan), and are unconnected with the Arabic muezsin; here the authors halted between two opinions. Clliap, 'wing,' is the Malay sayap. $D i$, $d \bar{i}$, the proposition 'in,' etc., is doubtless the same as the Malay $d i$ (not $t i$, as given in the dictionary). Tapak, 'droit devant,' etc., is not merely the Bahnar topat, but also the Malay tepat. Batan, 'net (for hare-hunting),' is not connected with the Malay bènang (meaning 'thread'), but is a word that reappears in the sense of 'net' in other languages of the Eastern Archipelago. The late Dr. Brandes, whose death is so deeply lamented by all who take an interest in Malayo-Polynesian research, long ago suggested that this was the stem of the common word for 'animal' (Malay binatang, Cham banatan), which in that case must have originally meant ' animal caught in a net.' 'Badan, 'body,' is an Arabic word, as stated, but the Malagasy vatană, given as cognate with it, has nothing to do with it, being related to another word (Malay batany), which in several MalayoPolynesian languages means 'trunk,' especially of a tree, but also in some cases the trunk of the human body. Dahlău, 'formerly,' is from halău, 'head,' and is equivalent to Mal. dahulu. Darak, 'sea,' is probably connected with Mal. darat, 'land'; in the Philippines the word occurs with the former meaning. Jal, 'net,' like the Mal. jala, is presumably of Indian origin, only the Cham word has the typical Mon-Khmer and Indo-Chinese monosyllabic form. Padam, dam, ' to put out a light,' must be the Mal. padam. For padak, 'sword,' compare the Mal. peedang. For padan, 'spacious,' and also the numeral coefficient for 'paillottes tressées,' one may compare the Mal. bidang, 'spacious,' etc., which is also the coefficient for kajang, 'awnings,' and the like, as well as the Mal. padang, 'plain,' 'open space.' The root appears to convey the idea of 'breadth' simply. I doubt if badan, 'to make manifest,' can be connected with the Mal. bentang; I think it must be classed with the Javanese padang, 'clear,' and perhaps also the Old Khmer dan, ' to see' : compare the Mal. pandang, 'to look.' Here also goes the Cham word bidan, 'clairement,' which cannot 
be connected with the Bugis mita, Mal. lihat, or Sanskrit vidã, as the authors suggest. Duhrakãa, 'péché,' 'pécheur,' 'enfer,' represents two distinct Sanskrit words, which occur in Malay under the forms dërhaka, 'treason,' 'traitor,' and naraka, 'hell.' Bala, balā, 'mal,' 'malheur,' is the Arabic بلا which reappears in Malay as bala. Baluv, pronounced balău, 'fallow,' 'widower,' 'widow,' is the Malayo-Polynesian walu, balu, 'widow,' 'widower.' Riya, riy $\bar{a}$, riyya, in such expressions as jalan riy $\bar{a}$, 'the public road,' kraun riy ā, 'a big river,' is the same word as the Malay and Achehnese raya, 'large,' 'grand'; the rootmeaning is 'big,' not 'royal,' and the word has nothing to do with the Indian räja, 'king.' Javap, 'reply,' is unquestionably from the Arabic جواب , jawãb (not juāb), and there was no need to query it. Pation, 'white,' 'fair,' is probably identical with the Mon on $\mathcal{E}$, 用 $\mathcal{E}$ (ptain. btän, pronounced pëtain), 'white.' Pruòo', ' belly,' and prać, 'entrails,' 'bowel,' are perhaps connected with the Malay perrut, Achehnese prëut, 'belly,' which in some of the cognate languages of the Archipelago also means 'entrails.' (Final $-c$ interchanges in Cham with -t, e.g. kruodc, kruaic, 'orange,' 'lemon,' is the Achehnese kërruèt.) Pakai, 'to insult,' is clearly cognate to Mal. maki, which has the same meaning. Pajar, 'dawn,' is the Arabic in Malay as fajar and pajar. Pankat, 'tier,' is the Mal. pangkat. With pajain, 'seed,' 'race,' compare the Mal. biji, bijeh. Avan, 'to embroider,' appears to be the same as the Mal. awan, 'cloud,' 'pattern (in artistic design).' On the other hand, the relation of parauh, 'to arrange troops into line,' to the Mal. baris, 'line,' seems very dubious; and much the same must be said of the connection suggested by the authors between paraun, 'to destroy,' and Mal. pràn (sic: presumably perrang, 'to fight'). Tanöm, tanoöm, ' to bury,' is identical with Mal. tanam (which has the same sense), and the reference in this paragraph to tanoh, ' earth,' is unintelligible. Tunam, tamam, 'garden,' is probably Downloaded from https://www.cambridge.org/core. University of Leeds, on 24 Sep 2018 at 04:10:52, subject to the Cambridge Core terms of use, available at https://www.cambridge.org/core/terms. 
connected with tanam; there is also a Malay word taman, 'garden.' The root is probably tam, 'to plant,' which (as Professor Schmidt has pointed out) occurs in several MonKhmer languages. Tamat, 'end,' 'finished,' is the Arabic تمّن Tañi, 'ear,' a mere variant of $\tan \bar{\imath}$, should not have been put into the same paragraph with the quite distinct word taña, 'to question.' Tasak, ' ripe,' is rightly connected by the authors with the Mal. masak, but they should also have cited the Kawi, Balinese, and Batak tasak, which are better parallels than the Malay word. I cannot see any connection between kalin, 'rebel,' 'peril,' 'war,' etc., and the Mal. perrkélahian, 'quarrel,' and I doubt the identity of halun, hulun, 'slave,' and the Mal. hulur. The word nan, 'food,' appears to be the same as the root of the Javanese pangan, 'to eat.' Sakavin, sakavain, 'dowry,' appears to be the Mal. isi kahwin (this last being a Persian word). Satru, 'enemy,' even if it does come from the Khmer satruv, is of Indian origin ; compare the Mal. sĕtěru. Hävā, 'covetous desire,' is probably the Arabic and Mal. هوي (pronounced hawa in Malay), not شهوته. These suggestions do not, of course, profess to be exhaustive.

The dictionary fills over 530 pages, and (including variants) contains something like 10,000 Cham words, each of which is given both in the native character and in a transliterated form. In many cases phrases and sentences are given in illustration of the use of particular words. In some cases there is an indication that the word in question belongs to the dialect of Camboja, or that of Annam; it were rather to be wished that this had been done throughout, though it appears that the two dialects are very closely allied. The dictionary proper is preceded by a valuable introduction, explaining the orthography, grammar, etc., of the language, and a useful bibliography, in which a great number of works dealing with the linguistics of the MonKhmer and Malayo-Polynesian families, etc., are enumerated. At the end come two indexes: one of the French equivalents used in the dictionary, and the other of the Cham words put into the order of the Roman alphabet. These will, Downloaded from https://www.cambridge.org/core. University of Leeds, on 24 Sep 2018 at 04:10:52, subject to the Cambridge Core terms of use, available at https://www.cambridge.org/core/terms. 
of course, greatly facilitate the use of the work for comparative purposes, which will, after all, probably be its chief utility. Altogether the work has been well done, and its authors must be heartily congratulated on the accomplishment of their great task. The thanks of Orientalists are also due to the Ecole Française d'Extrême Orient, under whose auspices it has appeared, as well as to the Imprimerie Nationale, which has printed the work in excellent style.

\section{O. Bragden.}

Arch arological Survey of Ceylon. Epigraphia Zeylanica, vol. i, parts 2 and 3 . Edited and translated by Don Martino de Zilva Wickremasinghe, epigraphist to the Ceylon Government. (London, 1907.)

Wickremasinghe has continued his publication of ancient inscriptions in the island of Ceylon, of which he had given us the first instalment in 1904 (see J.R.A.S., 1905, p. $183 \mathrm{ff}$.). Part 2 of vol. i contains the slab-inscription of Kassapa V (929-39) at Anurādhapura and the rock-inscriptions of Maha-Ratmale (135-41) and Perumaiyan-Kulam (66-110), part 3 the two tablets of Mahinda IV (97j-91) at Mihintale, and a slab-inscription belonging to the same king and situated near the stone-canoe at Anurädhapura.

All these inscriptions except the first and the last one have been published before, in my "Ancient Inscriptions in Ceylon" (London, 1882). Wickremasinghe's transcripts are in some places more correct than mine, but the facsimile of slab $\mathbf{A}$ of the Mihintale inscription which he has added to his volume (plate 14) is certainly not so legible as those given by me as No. 121 of my plates. As far as the translation of the inscriptions is concerned, Wickremasinghe has taken great trouble to give a better rendering, and in some cases he has done so with success. Thus, for instance, his explanation of the word dakapati=udakaprapti, given on p. 72 , seems to be preferable to those given by Goldschmidt, Franke, and myself, although I have not been able to find the Pāli dakapatti quoted by Wickremasinghe in support of his theory. 